\title{
Peaceful Use of the Sea and the Rule of Law
}

\author{
Miyoshi Masahiro
}

It is a truism to say that the rule of law should prevail in international relations. The rule of law implies "the subordination of all authorities, legislative, executive, judicial, and other to certain principles which would generally be accepted as characteristic of law, such as the ideas of the fundamental principles of justice, moral principles, fairness and due process." ${ }^{1}$ Consequently, political or policy considerations in favour of national interests without heed to their legal implications are outside the realm of law. The rule of law is easy to say, but not necessarily easy to materialise in the actual world where various national interests and cultural-historical backgrounds tend to collide with each other. Despite some uncertainty of its concept, however, the rule of law should be the governing principle for the conduct of States in their mutual relations.

\section{$1 \quad$ Importance of Peaceful Use of Sea Resources}

Article 88 of the United Nations Convention on the Law of the Sea (hereinafter, "UNCLOS") provides: "The high seas shall be reserved for peaceful purposes." Naturally, this does not automatically apply to all sea areas but, in view of its clear intent, may be applicable mutatis mutandis to the exclusive economic zone (hereinafter, "EEZ") where non-coastal States may have a share in the living resources on the basis of specific arrangements with the coastal State. ${ }^{2}$ The living resources are absolutely necessary for everyday life of the populations in the coastal State. But "[w] here the coastal State does not have the capacity to harvest the entire allowable catch, it shall ... give other States access to the surplus of the allowable catch ...."3 Full benefits from the resources may be ensured by peaceful means of exploitation. Should there be disagreement among the neighbouring coastal States as to an effective use of the resources, it could lead on to an abusive use by some impudent States to the exclusion of others a state of lawlessness. Protecting fishing vessels by some accompanying warships from possible coast guard interventions of the coastal State, as was

1 David M. Walker, The Oxford Companion to LaW 1093 (1980).

2 See unClos, Article 62.

3 UNCLOS, Article 62, para. 2.

(C) MIYOSHI MASAHIRO, 2019 | DOI:10.1163/9789004379633_002

This is an open access article distributed under the terms of the prevailing CC-BY-NC License at the time of publication. 
occasionally evidenced in the South China Sea, is by no means a peaceful act. That aggressive State is taking advantage of the non-existence of a legal arrangement for fishing in the sea area in question.

To take Japan's fishing arrangements, for example, it has a fishing agreement of 1998 with South Korea ${ }^{4}$ in the Sea of Japan and the East China Sea and another of 1997 with China $^{5}$ in the East China Sea. Both are naturally results of political compromise and have some defects respectively. Even with some such defective aspects, they are workable arrangements. The most recent fisheries arrangement in the East China Sea is that of 10 April 2013 with Taiwan, ${ }^{6}$ which responds to the daily needs of fishermen from Taiwan who used to fish in the waters near the Senkaku Islands but have been virtually excluded from those waters over the past few decades.

With respect to non-living resources, however, the basic legal order in which Japan is placed is not complete. It has two continental shelf agreements of 1974 with South Korea ${ }^{7}$ but no EEZ agreement yet. The matter is much worse in its relations with China: it has no basic agreement on the continental shelf nor on the EEZ. All it has in this regard is a broad arrangement by means of a brief press release of 2008 for joint development of natural gas in the East China Sea. ${ }^{8}$ This has yet to be completed by further implementing arrangements, but no effective results have since been achieved. It is a matter of regret that no clear

4 The Japan-South Korea Fisheries Agreement (entered into force 22 January 1999).

5 The Japan-China Fisheries Agreement (entered into force 1 June 2000). For a brief introductory analysis of this agreement, together with the Japan-South Korea agreement, see, for example, Masahiro Miyoshi, New Japan-China Fisheries Agreement: An Evaluation from the Point of View of Dispute Settlement, 41 The Japanese Annual of International LaW 30-43 (1998).

6 Japan Business Press, available at http://jbpress.ismedia.jp/articles/-/37570.

7 For the text of the two agreements of 30 January 1974, see, for example, JonATHAN I. CHARney and Lewis M. Alexander (eds.), International Maritime Boundaries, VOLUMe 1 1063-1068, 1073-1089 (1993).

8 On 18 June 2008, the Governments of Japan and China issued a brief joint press release on "Co-operation between Japan and China in the East China Sea," composed of two instruments of understanding. For a brief description of this joint press release, see, for example, Masahiro Miyoshi, Japan's Arrangements with South Korea and China for the Development of Oil and Gas in the East China Sea: A Memorandum, an abridged version of a paper filed with the Centre for the Sea and Maritime Law of the Faculty of Law of the National University of Hanoi, Vietnam, and presented as a discussion paper at the Roundtable, Maritime Boundary Delimitation and Possibilities of Joint Development in East and Southeast Asia, co-sponsored by The Aichi University Institute of International Affairs and the Centre for the Sea and Maritime Law of the Faculty of Law of the National University of Hanoi, Vietnam, held on Kurumamichi, Nagoya, Campus of Aichi University on 29 November 2008, and reproduced in the 134 Journal of International Affairs 114-120 (2009). 
response has been forthcoming from the Chinese side over the past five years to repeated Japanese calls for a re-start of negotiations for implementation.

\section{2}

Military Expansionist Trends

With its growing economy over the past decade, China is showing a move to increase its advances into the western Pacific sea areas. It has been claiming advances beyond the "First Island Chain" and into the "Second Island Chain" in the Northwest Pacific and a tongue-shaped or U-shaped dash line in the South China Sea. ${ }^{9}$ Thus, it has created a concern among the States in this region, particularly because it is viewed as an expansionist move backed by the Navy of the People's Liberation Army. As it is linked to territorial claims to some islands, islets and other smaller insular formations, the move is being viewed as not only resource-oriented but also territorial expansionist. The widely shared concern has been recently reinforced by the Chinese Government's official proclamation that China will resolutely defend its sovereignty over the islands and islets as its "core interest."10

Whether the attempt to advance into the western Pacific is an alleged "core interest" is a matter for China. But it has undeniable repercussions on the States in this part of the world, and consequently is unacceptable to them in its alleged form. In other words, a mere proclamation of "core interest" does not entitle the claimant to its claimed territory under international law. It involves a great number of islands, islets and smaller insular formations which have large surrounding areas of the sea where there are good fishery grounds and potential hydrocarbon and other mineral resources. The other States in this region have overlapping claims to those islands, islets or smaller insular formations and long-time interests in the surrounding seas, and seem to be perplexed in the face of the recent Chinese moves. To make the matter worse, such moves for maritime advances are backed by the military. ${ }^{11}$ It is even suspected that the military is taking the initiative in those advances. If this is so,

$9 \quad$ For a discussion of the "U-shaped line," see, for example, Masahiro Miyoshi, China's 'U-Shaped Line' Claim in the South China Sea: Any Validity Under International Law?, 43 Ocean Development and International LaW, 1-17 (2012).

10 See the public announcement by the Foreign Ministry spokeswoman, Hua Chunying, at the press conference on 26 April 2013, reported in The JAPAN Times, 28 April 2013, at 2, which says the announcement was made for the first time that the Senkaku Islands is regarded as a "core interest" just as Taiwan, Tibet, and the restive Xinjiang Uyghur Autonomous Region are.

11 See, for example, the recent Scarborough Shoal incident between China and the Philippines, and the earlier conflict between China and Vietnam over the Paracel Islands. 
the concern of the neighbouring States is more serious because such advances into the sea could also create a security threat to those States.

If the naval units of the People's Liberation Army are actively involved in the Chinese advances into the western Pacific, those States in the region which think themselves threatened thereby would respond by building up their military forces. This could lead on to a vicious circle of military build-ups in this region. Every State concerned is well advised to refrain from more such military activism and make sincere efforts to come to terms with each other for effective utilisation of the rich sea resources.

II

History and International Law

When it comes to the basis of claim to sovereignty over an island or islet, or any other smaller insular formation for that matter, it is well known that China rests its claim on history or long-term assertion of sovereignty. As it has a very long history as a sovereign State, China would have abundant old documents and maps depicting the islands or islets concerned as its possessions overseas. But it is doubted whether history is everything or silences any otherwise grounded argument on territorial sovereignty.

\section{Discovery as an Historical Ground for Title to Territory}

Take, for example, the Senkaku Islands (Diaoyu in Chinese) problem. China has repeatedly asserted that its ancient historical documents depict those islands as belonging to China. ${ }^{12}$ It can be inferred from such depictions that it may have been the Chinese who sighted the islands first. If territorial sovereignty can be proved by such depictions alone, the Chinese assertions would be clearly correct. Discovery can have a legal effect, as indeed it used to have in the mediaeval years, but in the modern times it can only have a limited effect of inchoate title unless perfected within a reasonable time by effective occupation. ${ }^{13}$ However, such historical documents presented by China do not provide

\footnotetext{
12 See, for example, Tianying Wu, An Examination of the Title to the Diaoyu Islands before the Sino-Japanese War: Disproof of Messrs. OKuhara Toshio AND OTHERS (Japanese translation by Mizuno Akira) 31-48 (1998).

13 Perhaps the first step to show the will for appropriation, animus occupandi, is such symbolic acts as to display the national flag and arms. See, for example, the Award of the Permanent Court of Arbitration, dated 4 April 1928, in the Island of Palmas case, 2 RE Ports of International Arbitral Awards 857 (1928). See also, C.H.M. Waldock, Disputed Sovereignty in the Falkland Islands Dependencies, 25 British YeAr Book OF InTERnATIONAL LAW 323 (1948).
} 
the evidence that China has established effective controll4 over the disputed islands over the past hundreds of years. By effective control is meant a continuous and peaceful display of State authority or sovereignty without protest from foreign States. It means the animus occupandi, the clear intention to possess the territory, and the effectiveness of claims to sovereignty. The rationale of this requirement is that any territorial possession of a State in a remote place may be adversely occupied by another State before it is known to the original possessor State.

\section{$2 \quad$ The Legal Basis of Title to Territory}

While the main rules of modern international law, including those governing the acquisition of territory, are said to have been established in the late 19th century, the Island of Palmas arbitration of 1928 between the Netherlands and the United States wound up the law of acquisition of territory. ${ }^{15}$ As to whether a mere sighting or discovery is sufficient to constitute a title, the Award states:

[D] iscovery alone, without any subsequent act, cannot at the present time suffice to prove sovereignty over the Island of Palmas (or Miangas).... ${ }^{16}$

14 Here the term "effective control" is used, instead of "effective occupation" which is the normal term for the establishment of sovereignty, because it is commonly used to mean a continued state of "effective occupation."

15 The Island of Palmas arbitration, by the sole arbitrator Max Huber of Switzerland, before the Permanent Court of Arbitration has been esteemed among international lawyers as an authoritative exposition of the law of acquisition of title to territory. See, for example, Hazel Fox, Arbitration, in David Davies Memorial institute of International Studies, International Disputes: The Legal Aspects 109 (1972), where the author says: "... the award in the Island of Palmas case, 1928, was the most outstanding contribution to international jurisprudence."

16 The Island of Palmas Award, 2 Reports of International Arbitral Awards 846 (1928). As early as 1609 when his MARE LibERUm was published under a pseudonym, Grotius wrote:

To discover a thing is not only to capture it with the eyes but to take possession thereof

.... The act of discovery is sufficient to give a clear title of sovereignty only when it is accomplished by actual possession. (Emphasis added)

Hugo Grotius, Mare Liberum 11 (1916), as quoted in Waldock, op. cit., at 322. Likewise Goebel had this to say about the instruction of Charles V of Spain to his Ambassador in $15^{23}$ in the dispute with Portugal over the Molucca Islands:

Although Mollucco had been discovered by ships of the King of Portugal, it could not on this account ... be said that Mollucco had been found by him; for it was evident that to 'find' required possession, and that which was not taken or possessed could not be said to be found although seen or discovered.

Goebel, Struggle for the FalkLand Islands 96 (1927), as quoted in Waldock, op. cit., at $322-323$. 
[A]ccording to the view that has prevailed at any rate since the 19th century, an inchoate title of discovery must be completed within a reasonable period by the effective occupation of the region claimed to be discovered. ${ }^{17}$ (Emphasis added)

The Award further states on the weakness of an inchoate title of discovery:

But even admitting that the Spanish title still existed as inchoate in 1898 and must be considered as included in the cession under Article III of the Treaty of Paris, an inchoate title could not prevail over the continuous and peaceful display of authority by another State; for such display may prevail even over a prior, definitive title put forward by another State. ${ }^{18}$ (Emphasis added)

The logic of these findings has been followed in the subsequent judicial decisions on territorial sovereignty, for example, the Clipperton Island (1931), Eastern Greenland (1933) and Minquiers et Ecrehos (1953) cases. ${ }^{19}$ The decisive test of a State's title in the modern law, according to Waldock, is not having the

17 The Island of Palmas case, 2 Reports of International Arbitral Awards 846 (1928).

18 Ibid.

19 The Sentence du 28 janvier 1931 in the AfFaire de L'Île de Clipperton states:

... même en admettant que la découverte ait été faite par des sujets espagnols, il faudrait, pour que la thèse du Mexique fut fondée, prouver que l'Espagne, non seulement avait le droit, en tant qu'État, d'incorporer l'île à ses possessions, mais encore l'avait effectivement exercé.

2 Reports of International Arbitral Awards 1109 (1933). The judgement of 5 April 1933 of the Permanent Court of International Justice in the Legal Status of Eastern Greenland case says:

[A] claim to sovereignty based not upon some particular act or title such as a treaty of cession but merely upon continued display of authority, involves two elements each of which must be shown to exist: the intention and will to act as sovereign, and some actual exercise or display of such authority.

PCIJ, Series A/B 53, at 27-28. The judgment of the International Court of Justice in the Minquiers et Ecrehos case of 1953 has this to say:

What is of decisive importance ... is not indirect presumptions deduced from events in the Middle Ages, but the evidence which relates directly to the possession of the Ecrehos and Miquiers groups.

ICJ REPORTS 1953, at 53. Waldock extensively discusses the constituent factors of the exercise or display of sovereignty based on the three cases of Island of Palmas, Eastern Greenland, and Clipperton Island, saying that it must be $(a)$ peaceful, $(b)$ actual, $(c)$ sufficient to confer a valid title to sovereignty, and $(d)$ continuous. WALDOcK, op. cit., at 334-337. 
territory at its apparent disposition but the exercise of the functions of a State in a manner appropriate to the circumstances of the territory and to the extent necessary to fulfil the obligations of a State under international law. ${ }^{20}$

Thus, a mere discovery, even if it is duly recorded, cannot in itself constitute a title to sovereignty unless it is perfected within a reasonable period of time by effective occupation of the target territory. In the case of the Senkaku Islands, the Japanese Government had made a series of careful research to make sure that they were not under effective control of any State before it formally incorporated them into the Japanese territory at a Cabinet meeting in $1895 .{ }^{21}$ Technically, it did so as a matter of occupation, rather than prescription, under international law because they were terra nullius. ${ }^{22}$ It was a lawful acquisition of title requiring no passage of time. Had the acquisition been a case of prescription, it should have been the acquisition of title to the islands by a long-continued and undisturbed possession. ${ }^{23}$

\section{$3 \quad$ Inter-temporal Law}

In this connection, some words would be in order about the concept and role of inter-temporal law. The act of incorporating the Senkaku Islands into the Japanese territory in 1895 was lawful at the time of the act under inter-temporal law. If one criticises its legality today, one does so under international law of

20 WALDOCK, op.cit., at 324-325.

21 An episode shows how carefully the Japanese Government treated the sovereignty problem of the Senkaku Islands before it formally incorporated them in the Japanese territory. In 1894, when Koga Tatsushiroh applied to the Governor of Okinawa Prefecture for a loan of some Senkaku Islands to implement his plan of developing them after some ten years of exploration for feathers, guano and marine products, the Okinawa Governor turned down his application on the ground that the islands were not formally appropriated by any State yet. Subsequently, in August 1896, a year and a half after the Cabinet decision to incorporate the islands into Okinawa in 1895 , his request was approved by the Interior Minister for a 3o-year loan free of charge. Toshio Okuhara, Senkaku Islands and Japan's Ownership of Them: A Historical Review of their Incorporation into the Japanese Territory" (in Japanese), 234 JAPAN AND THE World MAgazine 21-37 (1979).

22 The reader is referred to a very careful study of the Senkaku Islands problem by Shigeyoshi Ozaki, Professor Emeritus of international law, Tsukuba University, Japan. His most recent paper, Territorial Issues on the East China Sea: AJapanese Position (this is an erroneous title of the paper adopted by the editor to conform to the title of the Chinese counterpart's paper), 3(1) Journal of EASt Asia ANd International LAW 151-174 (2010), is a handy abridged English version of his full-scale study based on his thorough-going research over the past thirty years or so. Besides discussing the international law issues involved, it scrupulously refutes the alleged historical basis of China's claimed title by examining the maps and the names of the islands. Ibid., at $155^{-164}$.

23 See R.Y. Jennings, The ACQuisition of Title to Territory in International LAW 20, 23 (1963). 
today. That is not the correct application of the law. As the Island of Palmas Award said,

Both Parties are also agreed that a juridical act must be appreciated in the light of the law contemporary with it, and not of the law in force at the time when a dispute in regard to it arises or falls to be settled. ${ }^{24}$ (Emphasis added)

Viewed from this statement of the Award, China's criticism of the Japanese incorporation of 1895 has been made in the light of "the law in force at the time when a dispute in regard to it arises or falls to be settled." That is against inter-temporal law.

The basis of inter-temporal law is that law evolves in the course of time. The law of the Middle Ages, for example, does not necessarily hold true in the modern years. Thus, the law of acquisition of title to territory has changed since the Middle Ages or early modern times. If, therefore, the Senkaku Islands had been discovered and so recorded in some historical documents in the early years of the Ming Dynasty, they could have been rightfully claimed to be Chinese territory under the international law of that time. ${ }^{25}$ But the law of territorial acquisition underwent changes through the ages of Spanish-Portuguese territorial expansions and other European States' scrambles for territory on the African continent during the $17^{\text {th }}$ to 19 th centuries, requiring the effective occupation and control of the claimed territory. The Island of Palmas Award states:

It is admitted by both sides that international law underwent profound modifications between the end of the Middle-Ages and the end of the rigth century, as regards the rights of discovery and acquisition of uninhabited regions or regions inhabited by savages or semi-civilised peoples. ${ }^{26}$ (Emphasis added)

242 Reports of International Arbitral Awards 845 (1928).

25 An early arbitral award in the Netherlands-Venezuela Island of Aves case, dated 30 June 1865 , recognised the validity of discovery as the basis of title to territory. H. LA Fontaine, Pasicrisie Internationale 1794-1900: Histoire documentaire des Arbitrages internationaux 152-153 (1997); 28 Reports of International Arbitral Awards 119-123 (French translation of the Award) (1817). But this is an isolated early case recognising discovery as the basis of title, and was soon overturned by the practice of States which placed more emphasis on effective occupation, as did the Island of Palmas Award in 1928. 2 Reports of International Arbitral Awards 845 (1928). 


\section{$4 \quad$ Effective Occupation (or Control)}

The factor of effective occupation (or control) has been confirmed as the decisive factor in the acquisition of title in the subsequent international judicial decisions, including the Clipperton Island, Eastern Greenland, Minquiers et Ecrehos cases among others. ${ }^{27}$ This logic has further been reconfirmed, in terms of effectivités, in more recent territorial cases before the International Court of Justice (hereinafter "ICJ") and arbitral tribunals, including the Burkina Faso/MaliFrontier Dispute (1986), Libya/Chad TerritorialDispute (1994), Eritrea/ Yemen Territorial Sovereignty and Scope of the Dispute (First Stage, 1998) cases. ${ }^{28}$ In the still more recent territorial dispute cases before the ICJ, the parties have abundantly pleaded effectivités, and the Court has duly responded by discussing effectivités. ${ }^{29}$ Thus State practice, as well as the jurisprudence of the ICJ and arbitral tribunals, shows the critical importance of effective control as an indication of animus occupandi. ${ }^{30}$ Consequently, it is safe now to say that discovery

$27 \quad$ See note 19 and accompanying text.

28 See, for example, the Burkina Faso/Mali Frontier Dispute case of 1986, ICJ RE ponts 1986, at 564, para. 18 and 620, para. 124. See also, the Libya/Chad Territorial Dispute case of 1994, ICJ RePorts 1994, at 22, para. 44; at 43 (Separate Opinion of Judge Shahabudeen); at 61, para. 40; 89, para. 128 (Separate Opinion of Ajibola); and 98-100 (Dissenting Opinion of Judge ad hoc Sette-Camara). Likewise, the Arbitral Award in the Eritrea/Yemen Territorial Sovereignty and Scope of the Dispute case (First Stage) of 1998 discusses effectivités in detail. 22 Reports of International Arbitral Awards 268-291, paras. 239-361 (1994).

29 For more subsequent cases discussing effectivités, see the Indonesia/Malasia Sovereignty over Pulau Ligitan and Pulau Sipadan case, ICJ Reports 2002; the Benin/Niger Frontier Dispute case, ICJ REPORTS 2005; the Nicaragua/Honduras Territorial and Maritime Dispute case, ICJ RePORTS 2007; the Malaysia/Singapore Sovereignty over Pedra Branca/Pulau Batu Puteh, Middle Rocks and South Ledge case, ICJ RePorts 2008; the Nicaragua/Colombia Territorial and Maritime Dispute case, ICJ REPORTS 2012; the Burkina Faso/Niger Frontier Dispute case, ICJ RE PORTS 2013.

30 However, it is worth noting that effectivités is not unrestricted but subject to "the critical date." See, for example, the Indonesia/Malaysia Sovereignty over Pulau Ligitan and Pulau Sipadan case, ICJ REPORTS 2002, at 682, para. 135, where the ICJ said:

[The Court] cannot take into consideration acts having taken place after the date on which the dispute between the Parties crystallized unless such acts are a normal continuation of prior acts and are not undertaken for the purpose of improving the legal position of the Party which relies on them.

See also the Nicaragua/Honduras Territorial and Maritime Dispute in the Caribbean Sea case, ICJ REPORTS 2007, at 698, para. 117, where the Court states:

Thus a critical date will be the dividing line after which the Parties' acts become irrelevant for the purpose of assessing the value of effectivités.

Furthermore the Nicaragua/Colombia Territorial and Maritime Dispute in the Caribbean Sea case states:

[T] he date upon which the dispute crystallized is of significance. Its significance lies in distinguishing between those acts à titre de souverain occurring prior to the date 
alone, unless perfected by effective occupation and control within a reasonable period of time, cannot constitute a title to territory in international law of today.

\section{$5 \quad$ Protest and Acquiescence in the Acquisition of Title to Territory}

Another important point which must not be overlooked in this connection is the complete lack of protest on the part of China at the time of the Japanese incorporation of the islands into its territory in 1895 and thereafter over a period of three-quarters of a century, until the late 1960s when all of a sudden it began to claim territorial sovereignty over the islands. It is extremely difficult to understand why China kept silence over such a long period of time if it considered the islands as its "core interest." Or did it not consider them a "core interest" in those days and did it begin to consider them a "core interest" in the late 1960 os or more recently? Such a failure to protest during the three-quarters of a century, during which there were various chances to lodge protests, ${ }^{31}$ is understood under international law to amount to acquiescence in the Japanese act of incorporation, and therefore China would now seem to be estopped from claiming a title to sovereignty over those islands. ${ }^{32}$

As Judge Ajibola says in his separate opinion in the Libya/Chad Territorial Dispute case of 1994, "There are many awards of international tribunals ... supporting the principles of estoppel or acquiescence in the sense of silence or absence of protest." He thus refers to the Alaska Boundary arbitration of 1903, the Delagore Bay arbitration of 1875, the Guatemala/Honduras Boundary

when the dispute crystallized, which should be taken into consideration for the purpose of establishing or ascertaining sovereignty, and those acts occurring after that date,

'which are in general meaningless for that purpose, having been carried out by a State which, already having claims to assert in a legal dispute, could have taken those actions strictly with the aim of buttressing those claims' (Territorial and Maritime Dispute between Nicaragua and Honduras in the Caribbean Sea (Nicaragua v Honduras), Judgment, ICJ REPORTS 2007 (II), at 697-698, para. 117).

ICJ REPORTS 2012, at 29, para. 67. Subject to the critical date, however, effective control is of crucial importance in its own right in the acquisition of title to territory.

31 It would have been known to the Chinese authorities that Koga Tatsushiroh was doing his business on a couple of Senkaku Islands since 1896 into the 1930s. Had they not had any knowledge of his business, they were to blame for their lack of diligence if they had thought the islands belonged to them.

32 For more detailed discussions on protest and acquiescence in international law, see Masahiro Miyoshi, Some Thoughts on Protest and Acquiescence in the Acquisition of Title to Territory: Implications for Territorial Claims in the East Asian Seas, a paper presented at the International Seminar on Geographical Features in the East Asian Seas and the Law of the Sea, Taipei, Taiwan, 20-21 September 2012. 
arbitration of 1933, the Grisbadarna arbitration of 1909 before he comes to the Island of Palmas case. ${ }^{33}$

\section{$6 \quad$ Policy and Law}

There would have been a change of policy on the part of China in its position on the Senkaku Islands ${ }^{34}$ as a result of the reported discovery of oil and gas fields in the sea areas around them by the scientific group which conducted seismic surveys there under the auspices of the United Nations Economic Commission for Asia and the Far East (hereinafter "ECAFE") in $1968 .{ }^{35}$ But if

33 ICJ Reports 1994, at 81, paras. 108-109. For the Alaska Boundary arbitration of 1903, the Guatemala/Honduras Boundary arbitration of 1933, and the Grisbadarna arbitration of 1909, see 15 Reports of International Arbitral Awards, 2 and 11, respectively. For the Delagore Bay arbitration of 1875 , see 66 British And Foreign State PAPERS (1874-1875).

34 Before its first-ever expression of opposition to the joint Japan-Korea-Taiwan moves towards the exploitation of the reported offshore oil and gas in the East China Sea in the Renmin Ribao (People's Daily) on 4 December 1970, China had failed, at least on two earlier occasions, to raise its claim to territorial sovereignty over the Senkaku Islands. In 1953 a news article appeared in the RENMIN RiBAO, suggesting China thought that those islands belong to Japan, because the article states, using the Japanese names for those islands:

The Ryukyu Islands are scattered to the North-West of our Taiwan and to the South-

West of Kyushu, Japan, including the seven island groups of Senkaku Islands, Sakishima

Islands, Daito Islands, Okinawa Islands, Ohshima Islands, Tokara Island, and Ohsumi

Islands.... (Emphasis added.)

This author's translation from the original Chinese text in RENMIN Ribao, 8 January 1953, at 4. This is a part of the report that has nothing to do with the ownership of the Senkaku Islands, and therefore should be an honest admission of Japanese sovereignty over those islands. Again in 1958 when China made a declaration of an administrative nature on the breadth of its territorial sea, it left out the Diaoyu islets among the islands that belong to it. The relevant part of this declaration states:

... Taiwan and its surrounding islands, the Penghu Islands, the Tungsha Islands, the Hshisha Islands, the Chungsha Islands, the Nansha Islands and all other islands belonging to China ....

The Declaration of 4 September 1958, para. 1, Peking Review, 9 September 1958, at 1. Should the Senkaku Islands be claimed to be included in "all other islands belonging to China," such an interpretation, though grammatically understandable, would rather weaken than strengthen China's position because the failure specifically to mention the name of Diaoyu implied no or little such interest of it in Diaoyu as it asserts today.

35 The group of scientists conducted the seismic surveys as part of the activities of the Committee for Co-ordination of Joint Prospecting for Mineral Resources in Asian Offshore Areas (hereinafter "CCOP"), then under the management of the ECAFE. The CCOP published a report on the seismic surveys in May 1969, which created a stir among the coastal States in this region by its concluding remarks: "A high probability exists that the continental shelf between Taiwan and Japan may be one of the most prolific oil reservoirs in the world." CCOP 2 TeChNical Bulletin 41 (1969). 
China realised the potential of oil and gas and decided to explore for it, it was a matter of policy decision, and not a matter of law. Law and policy must not be mixed up. However strongly China may assert that the islands are a "core interest" to it, it is at most a new policy consideration and cannot necessarily affect the law. In a word, such an assertion of policy has no opposabilité under international law. If China alleges that a change of policy entails a change in the law, it would be tantamount to saying: "Macht ist Recht."

\section{Dispute Settlement - Multilateralism vs. Bilateralism}

So far as the settlement of disputes is concerned, China has been known to have propensity for direct negotiations with its opponent or opponents. In respect of the insular disputes in the South China Sea, there has arisen the question of whether they are to be settled in a multilateral framework or through bilateral negotiations.

As early as 1976 the five original members of the Association of Southeast Asian Nations (hereinafter "ASEAN") - Indonesia, Malaysia, the Philippines, Singapore and Thailand - agreed to settle disputes among themselves through friendly negotiations. ${ }^{36}$ In 1997 China joined with the ASEAN States in making a joint statement on resolving disputes in the South China Sea "through friendly consultations and negotiations in accordance with universally recognised international law, including the 1982 UN Convention on the Law of the Sea."37 This important joint statement was endorsed in the 2002 Declaration on the Conduct of Parties in the South China Sea, which provides inter alia:

4. The Parties concerned undertake to resolve their territorial and jurisdictional disputes by peaceful means, without resorting to the threat or use of force, through friendly consultations and negotiations by sovereign states directly concerned, in accordance with universally recognised principles of international law, including the 1982 UN Convention on the Law of the Sea;

5. The Parties undertake to exercise self-restraint in the conduct of activities that would complicate or escalate disputes and affect peace and

36 The Treaty of Amity and Cooperation in Southeast Asia, 24 February 1976, Article 13, 1025 United Nations Treaty Series 316 (1976). (Emphasis added)

37 The 1997 Joint Statement of the Meeting of Heads of State/Government of the Member States of ASEAN and the President of the People's Republic of China of 16 December 1997, para. 8. (Emphasis added) 
stability including, among others, refraining from action of inhabiting on the presently uninhabited islands, reefs, shoals, cays, and other features and to handle their differences in a constructive manner. ${ }^{38}$ (Emphasis added)

This Declaration of 2002 was signed by China and ASEAN's ten members, and the undertaking has since been confirmed time and again. ${ }^{39}$ More recently, in July, 2011, China and the ASEAN members signed a document in this context: "Guidelines on the Implementation of the Declaration on the Conduct of Parties in the South China Sea." The Guidelines have yet to be approved by the governments of China and the ASEAN member States, but all sides called it a hopeful sign towards a peaceful resolution of the overlapping claims in the South China Sea. ${ }^{40}$

The question now is whether this can be taken as a firm commitment of China in its relations with the ASEAN States. The latest development at the time of this writing is that the Philippines has submitted its dispute with China over the Scarborough Shoal in the South China Sea to the International Tribunal for the Law of the Sea (hereinafter "ITLOS"), and the ITLOS announced on 25 April 2013 that it has chosen five arbitrators. ${ }^{41}$ But China has, as was expected, expressed its opposition to the ITLOS exercising its jurisdiction in this case. $^{42}$

As to China's approach to dispute settlement, a seasoned Indonesian diplomat reflecting on South China Sea issue once said:

38 The Declaration on the Conduct of Parties in the South China Sea, 4 November 2002, paras. 4, 5 .

39 See, for example, Xinhua news from Beijing, 23 December 2010: China, ASEAN Agree to Follow South China Sea Declaration, available at news.xinhuanet.com/english2010/ china/2010-12/23/c._13662098.

Kathy Quiano, China, ASEAN agree on plans to solve South China Sea dispute, CNN, 21 July 2011.

41 ITLOS/Press 191, 25 April 2013, which states that "[B]y a Notification and Statement of Claim dated 22 January 2013, the Republic of the Philippines instituted arbitral proceedings against the People's Republic of China pursuant to Annex viI to the Convention." The Philippines appointed a German national as a member of the arbitral tribunal but China failed to appoint a member of its choice within 30 days of receipt of the notification, as provided in Article 3, subparagraph (c), of Annex viI to the Convention, and the ITLOS President finally appointed four members, composing a total of five members of the arbitral tribunal. But as a result of Mr. M.C.W. Pinto stepping down as a member and President of the arbitral tribunal because of his family member's affiliation with one of the Parties, the ItLos President appointed Mr. Thomas Mensah as Mr. Pinto's replacement. ITLOS/Press 197, 24 June 2013. 
The issue of whether the prospect for solution would better be achieved bilaterally or through a regional approach still haunts the workshop until now. China is particularly keen on seeking bilateral solutions with each claimant, while the Southeast Asian claimants are not so sure whether this is the right approach .... I feel that the Southeast Asian claimants seem to have come to a conclusion that while bilateral dialogues and consultations would be useful, the solution to the Spratly claims would have to be in a regional context involving all claimants. ${ }^{43}$ (Emphasis added)

Should China, despite its ostensible accession to joint efforts for dispute settlement with the ASEAN States, continue to stick to its seemingly traditional approach, i.e., reluctance to accede to third-party settlement and preference for bilateralism on the one hand and should the ASEAN States never accept the Chinese bilateralism, there would be no way out of the present impasse in sight in the foreseeable future. What this writer is curious to know is whether China is traditionally averse to third-party settlement or whether such an attitude is a communist-oriented approach. ${ }^{44}$

\section{Conclusion}

Indeed, States seem to have a propensity for control over the settlement of disputes to which they are parties, and therefore preference for arbitration over judicial settlement, most typically the ICJ. ${ }^{45}$ Even so the ICJ Statute has provisions that if no judge of the nationality of one or both of the parties is included in the Court, that party or both parties may choose a person to sit as judge. ${ }^{46}$ This implies that even the ICJ allows an arbitration-like characteristic in the

43 Observation made by Hasjim Djalal, then ambassador-at-large of Indonesia, at a speech on the first day of the SEAPOL Tri-Regional Conference on Current Issues in Ocean Law, Policy and Management: Southeast Asia, North Pacific, and Southwest Pacific, Bangkok, 13 December 1994. Hasjim Djalal, The Spratly Islands Dispute: Prospects for SETtLement (unpublished text of the speech in mimeo) at 5 .

44 There seems to be good reason to suspect that the avoidance of a third-party settlement of disputes in favour of direct negotiations with their opponents has been the traditional policy of Communist regimes, the former Soviet Union among them.

45 For this propensity of States, see Masahiro Miyoshi, The State's Propensity for Control over Proceedings in the Settlement of Disputes, in Kathleen I. Matics AND Ted L. McDorman (eds.), Summary and Selected Papers of the seapol Tri-Regional Conference 106-112 (1995).

46 ICJ Statute, Article 31, paras. 2 and 3. 
composition of the bench, especially in view of its allowance of such choice in the composition of a chamber of three or more judges as well. ${ }^{47}$ Even if such a procedure does not ensure a strict application of the principle nemo judex in causa sua,${ }^{48}$ it is a third-party settlement and amenable to the rule of law.

A lesson may be learned from the Anglo-French Continental Shelf Arbitration of 1977. Originally, the United Kingdom wanted to go to the ICJ while France wanted an arbitration ${ }^{49}$ in which it could have more control over the choice of arbitrators. The consultations resulted in an arbitration in which the UK also had an equally comfortable control over the composition of the tribunal..$^{50}$ It has another aspect of control by the parties over the proceedings. The two Governments first agreed that "[a]ny question of the subsequent publication of the proceedings shall be decided by agreement between the two Governments." ${ }^{51}$ Subsequently they agreed not to publish them, thus avoiding possible embarrassing domestic effects of the Award. Despite such control over the procedural matters by the parties, this is a third-party settlement and reflects a spirit of the rule of law. One would do well to think well over the maxim: nemo judex in causa sua.

47 Ibid., Article 26, paras. 1 and 2. To the same effect the Statute of the International Tribunal for the Law of the Sea, Article 15, paragraph 2, provides that the Tribunal shall form a "chamber for dealing with a particular dispute submitted to it if the parties so request." (Emphasis added) Such a chamber is to be composed by the Tribunal with the approval of the parties. For its arbitration-like nature, see Rüdiger Wolfrum, Ad hoc Chambers, in JoN M. Van Dyke et al. (eds.), Governing Ocean Resources: New Challenges and Emerging Regimes-A Tribute to Judge Choon-Ho Park 275-283 (2013).

48 The Latin expression means: "No one should be a judge in his own cause."

49 France was said to have had a distrust of the ICJ's handling of publicity in the Nuclear Tests cases of 1974. Interview with Professor René-Jean Dupuy, counsel for the Government of France in this continental shelf arbitration, at Sophia University in Tokyo on 9 March 1978.

5o But after the two Governments basically agreed on arbitration, it took them another year or so formally to sign the compromis with the names of the five members of the arbitral tribunal specifically mentioned, indicating how difficult it was for them to agree on the composition of the tribunal. The parties each chose an eminent international lawyer of their nationality first and then agreed on the three other neutral arbitrators. See Compromis of 10 July 1975, Article 1, para. 1., 18 Reports of International Arbitral AwARDS 5 (1978).

$5^{1}$ Compromis, Article 9, para. 4, ibid., at 6. 